\title{
OBITUARY
}

\section{Dr. Abraham Flexner}

Abraham Flexngr was born in Louisville, Kentucky, on November 13, 1866, and died in Falls Church, Virginia, on September 21, 1959. Though not a physician, he played a leading part in the reform of American medical education which began early in this century; though not a scholar in the professional sense, he designed, created and was the first director of an institution for non-professional study of the most advanced type.

His parents were Hebrew immigrants from western Europe, pious, intelligent, courageous and uncompromising in the conduet of their home and the training of their children. Abraham was the sixth of seven sons. His eldest brother, Jacob, became the chief support of the family after financial disaster to their father in the panic of 1873 . Other brothers were Simon, who became the first director of the Rockefeller Institute, and Bernard, who gained distinction in law and literature. Their mother survived her husband by many years. Long after her death, Abraham wrote: "None of her children equalled her in respect to native endowment".

In his home, in the schools and the public library of Louisville, Flexner read many of the great classics of literature and history : one of his teachers inspired him with an enthusiasm for the study of Greek, which during his later life was "a flowing spring of interest".

In 1884 , financed by his brother Jacob, Abraham entered the Johns Hopkins University, which had been founded eight years earlier by Daniel Coit Gilman. He chose the classical group of studies, worked hard and obtained his bachelor's degree in two years. "Research was in the air we breathed". "President Gilman's wisdom and courage cannot be matched in the history of American education". "Those who know something of my work long after Gilman's day ... . will recognize Gilman's influence in all I have done or tried to do". Those sentences, quoted from his autobiography, reveal the indelible impress which Gilman and the Johns Hopkins made upon him.

For four years after returning to his mother's home he helped to increase the family income by teaching in the Louisville High School ; then, more through chance than design, he started a school of his own, which during the fifteen years of its existence prospered and became widely known for its excellence. President Eliot, for example, asked, "Why is it that your boys eome to our colleges younger and graduate in a shorter time than boys from our more famous schools ?"

Flexner's discovery of his own talents as a teacher, supplementing the influence of President Gilman and the Hopkins training, brought into being the passion for a career in education which was to direct the rest of his life. In its broader development, another factor was influential, the courage and foresight of his wife.

In 1898, Flexner married Anne Crawford, a highly gifted woman whose talents supplemented his. After fourteen years of the operation of her husband's school, she raised the question whether he was to remain content as a school teacher in Louisville for the rest of his life. The answer was "No". They decided to close the school, to go to Cambridge for $a$ year of graduate work at Harvard and then to spend two years, mainly in association with German scholars and in study of German educational organizations and methods. They made no further plans; this was their "leap in the dark".

During the third of these years, 1908, Flexner wrote his first book, "The American College", in which he analysed defects in the American collegiate system which he believed to be responsible for a student's loss of enthusiasm for scholarship during his college career.

The book came to the attention of the president of the Carnegie Foundation for the Advancement of Teaching, Henry S. Pritchett. Its impact led $\mathrm{Mr}_{\mathrm{r}}$. Pritchett to persuade Flexner to conduct an educa. tional study of medical schools in the United States and Canada. Supported also by the Council on Medical Education of the American Medical Association, the work was begun in December 1908 and the report published in 1910 as Bulletin No. 4 of the Carnegie Foundation. In histories of medical education in America it has justly been called "the beginning of a new era", the "Magna Charta of American medical education".

The survey was made from the point of view of an educator, not a practitioner. Each of the 155 schools then existing in the United States and Canada was visited and evaluated in terms of entrance require. ments, size and training of faculty, adequacy of laboratory and hospital facilities and amount and disposition of financial support. In Part 2 of the report each school was named, the verified facts in the above categories were stated, and a commentary, always frank and in many cases scathing, appended concerning faults and virtues.

Only some twenty schools were found to require two or more years of college for entrance; fifty others demanded four years of high school or 'equivalent', and many of these used that word as a way of evasion; the rest, grouped as basely mercenary, required little more than the rudiments or recollections of a common school education. Flexner's criticisms of these were fearless and uninhibited; conditions were described as "sordid, hideous, unintelligent even when honest" . . commercial schools characterized as "private ventures, money-making in spirit and object" which should be "crushed with all the force that law and public opinion can bring to bear".

The report had the effect of a bombshell ; in 1920 , ten years after its publication, the number of medical schools in the United States and Canada had decreased to eighty-five; in 1930, to seventy-six. In the remaining schools a wholesome, continuing ferment of self-examination was created.

The text of Part 1 is a treatise on medical education; its status in the United States in 1910 and a programme for improvement. It was novel in 1910 ; it is far from obsolete now. 
Space limitations permit mention only of the second Carnegie survey of medical education-that of Great Britain, France, Germany and Austriamade in 1910 and 1911 by Flexner and published in 1912 as Bulletin No. 6 of the Carnegie Foundation. Individual schools were not described in detail, only a picture of contemporary medical education in those countries being desired. The findings relating to Great Britain may perhaps be epitomized by quoting from an obituary notice in The Lancet of October 10 , 1959 : "It may not be too much to say that Flexner's ideas contributed to making medical education in this country something of which we may one day have reason to be proud".

Not only did the Flexner report accelerate the discontinuance of bad schools and stimulate the betterment of good ones, it also alerted philanthropic foundations other than the Carnegie to needs and opportunities in the field of medical education. In 1913 the Rockefeller-supported General Education Board, on advice from Flexner, allocated one and a half million dollars to the Johns Hopkins Medical School to be used to endow the chairs of medicine, surgery, pediatrics and obstetrics, so that their incumbents, relieved of the necessity of gainful practice, should devote their whole energies to teaching and research in the true university sense. This was the beginning of the 'full-time system' in clinical departments in the United States.

Also in 1913, Flexner was appointed to the administrative staff of the General Education Board; he later became secretary and director of studies. For fifteen years he guided the Board's allocations for medical education in such a way as to change its whole aspect in the United States. Those allocations amounted in toto to about 78 million dollars; they were distributed among medical schools of twentyfour universities, chosen because of ability and willingness to change. $\mathrm{He}$ developed remarkable skill in the technique of matching or contingent gifts, with the result that the 78 million dollars of Rockefeller money were made to add several hundred additional millions from other sources to American schools.

The results of these benefactions were by no means limited to the institutions to which they were made. The spirit of emulation caused many schools to do for themselves what otherwise would not have been done. In this sense the effects of Flexner's crusade became nation-wide.

In 1928 Flexner resigned from the secretaryship of the General Education Board, and its work in the field of medical education came to a close. During the spring of that year he gave the Rhodes Memorial Lectures at the University of Oxford, taking up residence in All Souls College during the term in which they were given. The entire following year was spent in gathering additional data and in rewriting the lectures previous to their publication as the book, "Universities : American, English, German". In addition to credit given for what was good, it contained outspoken criticism of "shameless humbuggery" in teachers' colleges and in home study and correspondence courses competing with on-thecampus work at certain named universities.

The book, as was doubtless expected, made a stir among educators; another result, unanticipated, was to determine the course of the next ten years of Flexner's life. This was the initiation of a succession of conversations with Mr. Louis Bamberger, a successful merchant of Newark, New Jersey, and his sister, Mrs. Felix Fuld, concerning philanthropies which they were in a position to support. This gave Flexner the opportunity to expound to them his long-held vision of what he later termed "a paradise for scholars, who, like poets and musicians, have won the right to do as they please and who accomplish most when enabled to do so". His exposition was so convincing that a grant of 5 million dollars was made to him with which to create what became the Institute for Advanced Study at Princeton, New Jersey.

The Institute was incorporated in May 1930 with Abraham Flexner, at the insistence of the founders, as the director. Mathematics was chosen as the first field of effort; Albert Einstein and Oswald Veblen were the first professorial appointments. It gives no scheduled courses ; awards no degrees ; admits only those judged to have "won the right to do as they please".

Now the Institute includes a School of Mathematics and a School of Historical Studies; there are fifteen permanent members who compose the faculty and fifteen other long-term members. There are at any one time about a hundred other members who are received for short periods-one or two years. They have come from all over the world. From the beginning of academic work in 1932 to the publication of a bibliography in 1955, the number of scholars who had taken advantage of the facilities was about 1,000; their publications of work done at the Institute were about 4,000 .

Concerning himself in relation to the Institute, Flexner has written, "It seems odd to me that never" until I met Mr. Bamberger and Mrs. Fuld did anyone dream that I could head an Institution. I was obviously regarded as too much given to innovation rather than administration. The charge was true, though misleading; for my feet were always on the ground, though always, it is true in motion".

"The director of the Institute must be constantly on the watch to prevent the invasion of the sort of routine and organization which may perhaps be indispensable to a university but would be death to the spirit of the Institute".

Flexner resigned the directorship in 1939, and was followed by Frank Aydelotte; he in turn, in 1947, by Robert Oppenheimer, the present incumbent.

In his autobiography, Flexner has made revealing comments on his qualities and on the circumstances which determined his career.

"I had in modest measure what Pasteur caller the prepared mind".

"I cannot see that I have pursued anything but an opportunistic course".

"I was quick to absorb, eager to execute. I got what in most cases $I$ wanted because $I$ reduced what I wanted to what I believed I could get".

"I have cared-cared profoundly-about education, and especially higher education, since at nineteen years of age I began to teach. But my interest has always been pragmatic. I wanted to do something - to teach this or that or to enable someone else to do it".

$\mathrm{He}$ was exceedingly intelligent; confident in his convictions; ardently imaginative; open to the informed opinions of others; utterly fearless in his devotion to excellence; both fearless and happy in his struggles against mediocrity and sham. Although he disclaimed the possession of originality, the genius with which he utilized the variety of his opportunities produced unprecedented developments in American education.
A. N. RICHARDS 